\title{
PENGARUH KONDISI SOSIAL TERHADAP PERILAKU PENGAMBILAN KEPUTUSAN PEREMPUAN PEMILIK UMKM JAWA TIMUR UNTUK MENGADOPSI E-COMMERCE
}

\section{Elya Kurniawati}

Jurusan Sosiologi Fakultas Ilmu Sosial Universitas Negeri Malang

Email elya.kurniawati.fis@um.ac.id

\section{Abstrak}

Persaingan ekonomi dunia belakangan ini didominasi oleh perusahaan yang mampu mengimplementasikan teknologi yang tepat ke dalam perusahaannya. Teknologi e-commerce memberikan banyak kemudahan yang dimanfaatkan oleh para pelaku usaha, tak terkecuali para perempuan pelaku Usaha Mikro, Kecil dan Menengah (UMKM) yang ada di Jawa Timur. Perempuan sangat potensial dan kompeten sebagai pelaku dan pengelola Usaha Mikro, Kecil dan Menengah (UMKM). Tujuan penelitian ini untuk mengetahui kondisi social yang berpengaruh terhadap perilaku pengambilan keputusan perempuan sebagai pemilik Usaha Mikro, Kecil dan Menengah (UMKM) untuk mengadopsi e-commerce. Penelitian ini dilakukan dengan menggunakan metode deskriptif kuantitatif. Sampel penelitian ini adalah 41 orang perempuan pelaku UMKM di Jawa Timur. Hasil penelitian menunjukkan bahwa mayoritas pemilik UMKM telah memiliki pengetahuan akan e-commerce, tetapi beberapa diantaranya masih belum mengadopsi $e$-commerce sebagai strategi bersaing perusahaannya.

Kata kunci: kondisi sosial; pengambilan keputusan; e-commerce; UMKM; perempuan

\section{THE EFFECT OF SOCIAL CONDITIONS ON DECISION MAKING OF WOMEN AS OWNERS OF EAST JAVA MSME TO ADOPT E-COMMERCE}

\begin{abstract}
Recent competition in economy is dominated by companies that are able to implement the right technology into their business. E-commerce technology provides many conveniences for business people, including women as owners of Micro, Small, and Medium Enterprises (MSME) in East Java. Women are very potential and competent as actors and managers of Micro, Small, and Medium Enterprises (MSME). The purpose of this study is to determine the social conditions that influence the decision-making of these women as owners of Micro, Small, and Medium Enterprises (MSMEs) to adopt e-commerce. This study was conducted using quantitative descriptive methods. Sample consisted of 41 women as owners of MSME in East Java. Data was analyzed using percentages. The results of the study show that the majority of these MSME owners have understood e-commerce, but some of them have not adopted e-commerce as their competitive strategy.
\end{abstract}

Keywords: social conditions, decision making, e-commerce, MSMEs, women 


\section{LATAR BELAKANG}

Kemajuan teknologi bergerak semakin cepat, terlebih setelah munculnya internet. Internet membuat perubahan dan perkembangan terjadi begitu cepat. Dunia bisnis tidak lepas dari pengaruhnya. E-commerce merupakan salah satu aplikasi yang memungkinkan penjualan dan pembelian terjadi melalui media elektronik, yaitu internet. E-commerce dapat mengakomodasi terjadinya proses jual-beli, pemasangan iklan, undangan, proses negosiasi hingga terjadinya suatu kontrak (Simpson dan Docherty, 2004).

Kartavianus (2012) mengatakan bahwa letak geografis tidak lagi menjadi pembatas dan dapat menghubungkan orang-orang secara luas hanya dengan penggunaan E-commerce. Pemesanan barang atau jasa pada e-commerce dilakukan di dunia maya, sehingga transaksi dapat dilakukan kapan saja dan dimana saja. Pemesanan tidak lagi harus terbatas oleh jam operasional toko ataupun jarak untuk mencapai toko. Transaksi dapat dilakukan 24 jam dalam sehari, 7 hari dalam seminggu. Hal ini menjadi sebuah jawaban dari permasalahan yang dihadapi oleh para pelaku bisnis di Indonesia. Seperti kita ketahui bahwa Indonesia merupakan negara kepulauan dengan persebaran yang tidak merata.

Perkembangan media internet juga membawa perubahan pada pola kehidupan sosial masyarakat Indonesia. Pengguna internet di Indonesia mencapai 123 juta orang di tahun 2018 setara dengan 50\% total populasi. Angka tersebut memposisikan Indonesia di peringkat ke-6 negara pengguna internet (Kominfo, 2019). Bolton Consulting Group (BCG) mencatat di tahun 2013 terdapat 74 juta orang Indonesia dalam golongan menengah dan diprediksi akan meningkat sebesar 54\% atau sejumlah 141 juta orang pada tahun 2020 (Sidarta dan Sidh, 2014). Baron (2003) menemukan bahwa penggunaan internet dapat menciptakan peluang baru bagi bisnis dengan perkembangan yang terjadi.

Kemudahan teknologi yang ada ditangkap sebagai peluang yang bagus bagi para pelaku bisnis untuk mengembangkan usahanya, tak terkecuali pada pelaku UMKM. UMKM berkontribusi penting dalam perekonomian dunia, hampir $90 \%$ nya disumbangkan oleh
UMKM (Lin, 1998). Di Indonesia UMKM merupakan sektor bisnis yang penting. Sebagian besar sektor bisnis yang ada didominasi oleh pelaku UMKM, yaitu sebesar 99,99\%. Kecilnya modal yang dibutuhkan membuat UMKM menjadi sektor bisnis yang mampu bertahan menghadapi krisis di tahun 1998. Mereka cenderung menggunakan modal sendiri sehingga tidak bergantung dengan fluktuasi mata uang asing. Bahkan pasca krisis, pertumbuhan UMKM semakin meningkat drastis (LPPI dan BI, 2015).

Meningkatnya pertumbuhan UMKM berbanding lurus dengan peningkatan sumbangsih UMKM terhadap pendapatan Negara. Terbukti bahwa tahun 2016 UMKM menyumbangkan PDB sebesar Rp 7.009.283 Milyar atau sebesar 59,84\% per tahun. Tahun 2017 sumbangan UMKM terhadap PDB Indonesia mengalami peningkatan menjadi $\mathrm{Rp}$ 7.704.635,9 Milyar atau sebesar 60\% per tahun (Kementerian Koperasi dan UKM, 2017). Tingginya angka tersebut membuat UMKM menjadi sektor bisnis yang menyumbangkan PDB terbesar. Berbagai dampak positif UMKM menjadikannya sebagai sektor bisnis yang sangat strategis untuk dikembangkan.

Sebanyak $50 \%$ usaha kecil di Indonesia saat ini dimiliki oleh perempuan. Angka tersebut menunjukkan bahwa peran perempuan dalam UMKM sangatlah tinggi. Perempuan berpotensi dalam meningkatkan roda perekonomian sangat besar. Perempuan aktif dalam pengembangan ekonomi suatu bangsa (Bastaman dan Juffiasari, 2015).

Para peneliti strategis seperti Eisenhardt \& Zbaracki (1992), mengemukakan bahwa proses pengambilan keputusan oleh wirausahawan pada organisasi kecil berbeda dengan proses pengambilan keputusan pada organisasi besar. Pada organisasi kecil, seorang wirausahawan merupakan pengambil keputusan tertinggi. Mereka melakukan pengambilan keputusan stratejik dan seluruh keputusan operasional (keseluruhan tingkatan strategi, yaitu strategi korporasi, strategi bisnis dan strategi fungsional). Sehingga proses pengambilan keputusan tersebut memang 
menjadi suatu hal yang sangat krusial dan penting bagi kelangsungan organisasi.

Pengembangan UMKM bergantung kepada pemilik usaha. Hal ini disebabkan karena dalam manajemen UMKM posisi kunci berada di tangan pemilik usaha, dimana hampir seluruh keputusan diambil oleh para pemilik. Proses pengambilan keputusan berperan besar terhadap perkembangan UKM. Robinson dan Pearce (2002) menyatakan bahwa pengambilan keputusan yang dilakukan merupakan kunci sukses sebuah organisasi, tak terkecuali bagi usaha kecil seperti UMKM. Sebagai usaha kecil, pengambilan keputusan UMKM tentu berbeda dengan yang terjadi pada organisasi besar ataupun perusahaan multinasional dan nasional yang ada. Pengambilan keputusan pada organisasi kecil seringkali dilakukan oleh pemilik organisasi yang kadangkala sangat mengandalkan jiwa kewirausahaannya. Busenitz dan Barney (1997) menyatakan bahwa wirausahawan lebih mudah terpengaruh sehingga keputusan yang dibuatnya seringkali bias dan alamiah dibandingkan keputusan yang dibuat oleh pengambil keputusan pada organisasi besar.

Pelaku UMKM bukan hanya didominasi oleh kaum laki-laki, kaum perempuan juga sangat potensial dalam melakukan dan mengelola kegiatan produktif dalam membantu perekonomian keluarga serta ekonomi nasional. UMKM yang dikelola perempuan memberikan kontribusi yang sangat strategis (Wicaksono dan Nuvriasari, 2012).

Faktor perilaku merupakan salah satu hal yang paling mempengaruhi pengambilan keputusan yang dilakukan. Kegiatan UMKM semakin berpusat pada manusia, merupakan menyebabkan individu menjadi faktor terpenting dalam proses perubahannya. Oleh karena itu, keputusan yang diambil secara secara individu oleh pemilik merupakan suatu hal yang sangat krusial dan penting bagi keberlangsungan organisasi. Ketidakmampuan suatu organisasi beradaptasi mampu menjadi pemicu kehancuran organisasi tersebut. UMKM diharapkan mampu bersaing dalam era perubahan saat ini (Kurniawati dan Saputra, 2018).

\section{METODE PENELITIAN}

Metodologi dalam penelitian ini bersifat deskriptif dengan pendekatan kuantitatif. Pengambilan sampel dilakukan pada 41 orang perempuan pemilik UMKM yang tersebar di beberapa wilayah Jawa Timur seperti Surabaya, Sidoarjo dan Malang. Teknik pengambilan sampel dilakukan dengan skala guttman dengan jawaban alternatif ya atau tidak. Skala guttman menggunakan skala kumulatif dimana jika individu setuju pada butir pertanyaan tertentu, maka individu tersebut juga setuju pada semua butir pertanyaan lain yang lebih lemah (pertanyaan sebelumnya). Analisis data dilakukan dengan cara penghitungan persentase. Kuisioner terdiri dari 4 item yang dapat menggambarkan kecenderungan pengaruh kondisi social responden tentang usia, tingkat pendidikan dan masa kerja terhadap keputusan dalam mengadopsi e-commerce.

\section{HASIL DAN PEMBAHASAN}

Penelitian ini dilakukan pada 41 orang perempuan pemilik UMKM di Jawa Timur yang tersebar di Surabaya, Sidoarjo dan Malang. Hasil yang didapatkan merupakan pengaruh kondisi sosial perempuan pemilik UMKM seperti tingkat pendidikan, usia, lama bekerja terhadap perilaku perempuan sebagai pemilik usaha, mikro, kecil dan menengah (UMKM) untuk mengadopsi e-commerce di Jawa Timur.

Tingkat pendidikan, kemampuan dan ketrampilan sangat berpengaruh dalam mengelola usaha. Tingkat ketrampilan dan pengetahuan (pendidikan) menyangkut beberapa aspek seperti dorongan individu, hasil dan dampak, kemampuan analisa, berfikir kreatif dan strategis, ketegasan dalam pengambilan keputusan, penilaian komersial, manajemen tim dan kepemimpinan, kemampuan beradaptasi, kemampuan merencanakan serta mengendalikan suatu proyek (Ardiana dkk, 2010). (Lihat Grafik 1) 


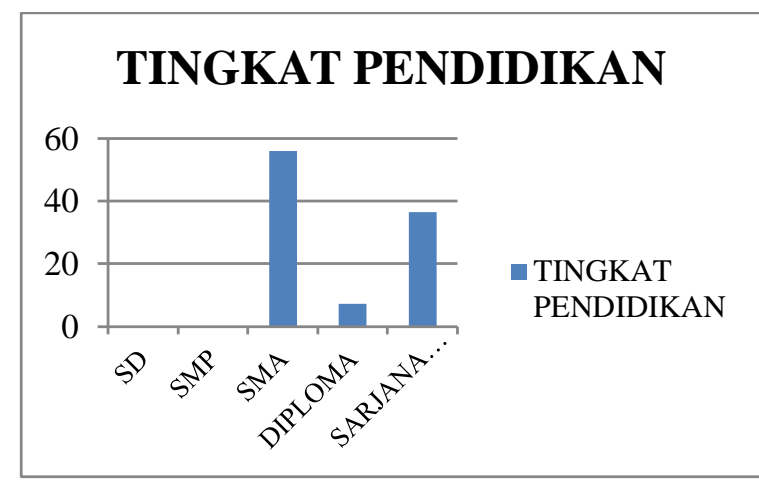

Grafik 1. Tingkat Pendidikan

(Sumber : Data Hasil Peneliti)

Dari grafik di atas dapat dilihat bahwa tingkat pendidikan perempuan pemilik UMKM paling rendah adalah setingkat SMA yaitu sebesar $56,1 \%$. 36,6\% perempuan menempuh pendidikan setara S1 atau di atasnya, serta 7,3\% telah mengenyam pendidikan pada level Diploma. Hal ini menunjukkan bahwa tingkat pendidikan perempuan saat ini telah mengalami peningkatan yang cukup tinggi. Hasil ini sejalan dengan apa yang dituliskan oleh Wibisono (2010) bahwa tingkat Pendidikan perempuan saat ini semakin tinggi.

Pendidikan mempunyai pengaruh yang besar terhadap produktivitas dan penghasilan individu. Tingginya kemampuan sumber daya manusia mampu meningkatkan kualitas hidup seseorang melalui proses pendidikan, pelatihan dan pengembangan yang mampu meningkatkan produktivitas kerja. Artinya semakin tinggi pendidikan seorang pemilik usaha maka penghasilan yang dihasilkan juga akan semakin meningkat (Nainggolan, 2016).

Tingkat Pendidikan perempuan sangat berpengaruh pada kemampuan dan ketrampilan dalam mengelola usaha. Tingkat ketrampilan dan pengetahuan (pendidikan) menyangkut beberapa aspek seperti dorongan individu, hasil dan dampak, kemampuan analisa, berfikir kreatif dan strategis, ketegasan dalam pengambilan keputusan, penilaian komersial, manajemen tim dan kepemimpinan, kemampuan beradaptasi, kemampuan merencanakan serta mengendalikan suatu proyek (Ardiana dkk, 2010).

Pendidikan menunjukkan pengaruh terhadap produktivitas usaha di Negara Afrika Selatan (GEM, 2011). Penelitian Mdatsane
(2012) di Afrika Selatan juga menunjukkan bahwa pengalaman bekerja, tingkat pendidikan serta usia umur usaha secara bersama-sama memberikan pengaruh yang signifikan terhadap kemajuan dan penghasilan usaha (Chiliya, 2012).

Peningkatan pendidikan dan keterampilan sangat dibutuhkan dalam pengelolaan usaha agar dapat semakin berkembang. Namun, pada kenyataannya banyak usaha perempuan yang terpuruk walaupun mereka memiliki skill yang baik dalam menjalankan usahanya tetapi berpendidikan rendah (Praminingtyas, 2010). Rendahnya tingkat pendidikan juga dapat mempersulit perempuan untuk mendapatkan akses pembiayaan UMKM dari pihak bank. Hal ini menyebabkan banyak diantara mereka yang terjerat hutang pada rentenir, sehingga mereka tidak berhasil mengembangkan usaha mereka dan menjadi semakin terpuruk (Indiworo, 2016).

Selain itu, usia juga turut memberikan pengaruh pada perilaku perempuan sebagai pemilik UMKM. Hasil yang tertera pada tabel di atas menunjukkan bahwa UMKM yang ada di Jawa Timur dominan dimiliki oleh perempuan dengan rentang usia antara 40-50 tahun. Dimana terdapat $56,2 \%$ responden yang berada pada rentang usia 40-50 tahun. Responden pada rentang usia 20-30 tahun, 30-40 tahun serta diatas 50 tahun masing-masing berjumlah $14,6 \%$. Hal ini menunjukkan bahwa para perempuan pemilik UMKM didominasi oleh perempuan-perempuan yang sudah memiliki tingkat kedewasaan usia matang. (Lihat Grafik 2)

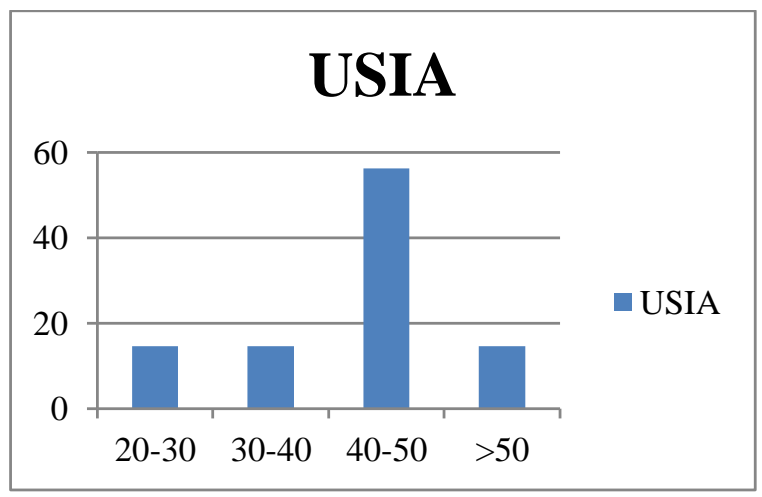

Grafik 2. Usia

(Sumber : Data Hasil Peniliti) 
Kematangan berfikir dapat dipengaruhi juga oleh tingkat pendidikan, kemampuan dan ketrampilan yang pada akhirnya juga berpengaruh pada kemampuan mengelola usaha. Tingkat ketrampilan dan pengetahuan menyangkut beberapa aspek seperti dorongan individu, hasil dan dampak, kemampuan analisa, berfikir kreatif dan strategis, ketegasan dalam pengambilan keputusan, penilaian komersial, manajemen tim dan kepemimpinan, kemampuan beradaptasi, kemampuan merencanakan serta mengendalikan suatu proyek (Ardiana dkk, 2010).

Febriani (2002) menyebutkan kelebihan perempuan yang dapat menjadi faktor pendorong keberhasilan usaha perempuan antara lain telaten, jujur, lebih dipercaya, ulet, sabar, teliti, tekun, serius, tangguh, berani mengambil resiko, tidak mudah menyerah, berdedikasi tinggi, semangat, kemauan keras, bekerja dengan iklas, menjaga nama baik, tidak egois, loyalitas tinggi tidak mudah menyerah, disiplin administratif maupun keuangan. Sifat-sifat tersebut membuat perempuan berfikir jauh dalam pengambilan keputusan. Mereka cenderung berfikir dan memiliki orientasi jangka panjang.

Hal ini sejalan dengan apa yang dituliskan oleh Kurniawati dan Saputra (2018) yang menyatakan bahwa Orientasi Jangka Panjang (Long-term Orientation) berkaitan dengan pola piker yang ada dalam masyarakat. Pada masyarakat yang memiliki orientasi jangka panjang, mereka cenderung menonjolkan status, sikap hemat, ketekunan dan memiliki rasa malu yang tinggi.

Ketrampilan yang menjadi dasar dari keahlian biasanya terbentuk dari lamanya masa mereka bekerja. Grafik 3 di bawah ini menunjukkan hasil tentang pengalaman kerja para perempuan sebagai pemilik UMKM di Jawa Timur.

Grafik pengalaman kerja menunjukkan bahwa perempuan pelaku UMKM di Jawa Timur sebagian besar yaitu sekitar $63,4 \%$ baru bekerja selama 1-5 tahun. 29,3\% perempuan telah mengelola usahanya selama 6-10 tahun. $7,3 \%$ diantaranya telah mengelola usaha mereka dalam kurun waktu 11-15 tahun. Hal ini menunjukkan bahwa pengelolaan UMKM ini kebanyakan masih berada di level awal perintisan. Semakin lama perempuan menekuni bidangnya maka keterampilan mereka dalam mengelola dan mengambil keputusan akan semakin tinggi juga. (Lihat Grafik 3)

Pengalaman kerja seseorang dapat meningkat seiring dengan lama waktu mereka bekerja. Semakin lama mereka bekerja, maka semakin tinggi pula ketrampilan yang mereka miliki. Tingkat ketrampilan sangat berpengaruh pada kemampuan mengelola usaha. Tingkat ketrampilan dan pengetahuan menyangkut beberapa aspek seperti dorongan individu, hasil dan dampak, kemampuan analisa, berfikir kreatif dan strategis, ketegasan dalam pengambilan keputusan, penilaian komersial, manajemen tim dan kepemimpinan, kemampuan beradaptasi, kemampuan merencanakan serta mengendalikan suatu proyek (Ardiana dkk, 2010).

Tingginya kemampuan sumber daya manusia mampu meningkatkan kualitas hidup seseorang melalui proses pendidikan, pelatihan dan pengembangan yang mampu meningkatkan produktivitas kerja (Nainggolan, 2016). Penelitian Mdatsane (2012) di Afrika Selatan juga menunjukkan bahwa pengalaman bekerja, tingkat pendidikan serta usia umur usaha secara bersama-sama memberikan pengaruh yang signifikan terhadap kemajuan dan penghasilan usaha (Chiliya, 2012).

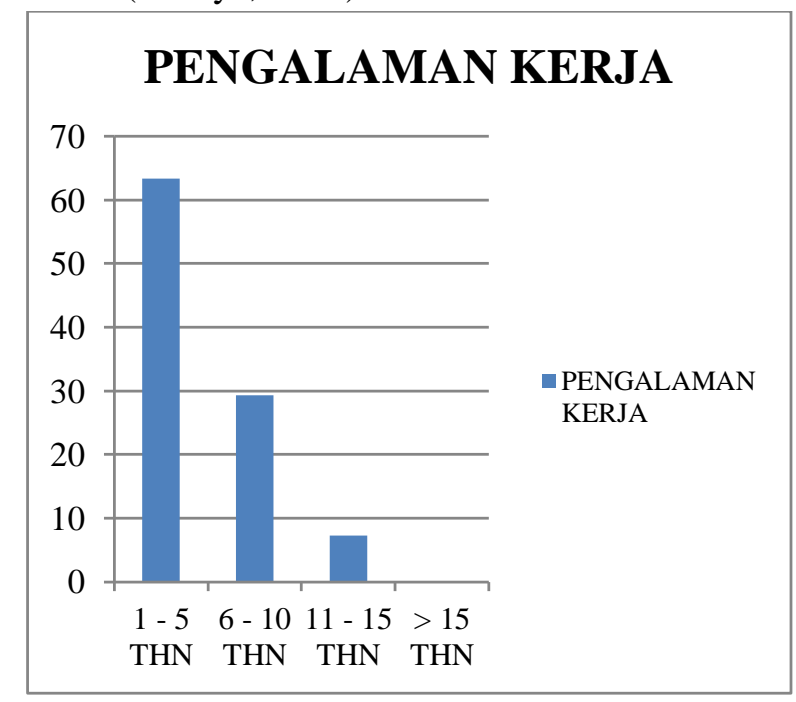

Grafik 3. Pengalaman Kerja

(Sumber : Data Hasil Peniliti) 
Ketiga kondisi sosial seperti tingkat pendidikan, usia, pengalaman bekerja yang telah diuraikan di atas dapat memberikan pengaruh pada perilaku perempuan sebagai pemilik UMKM di Jawa Timur dalam pengambilan keputusan untuk melakukan adopsi e-commerce bagi kemajuan usaha mereka.

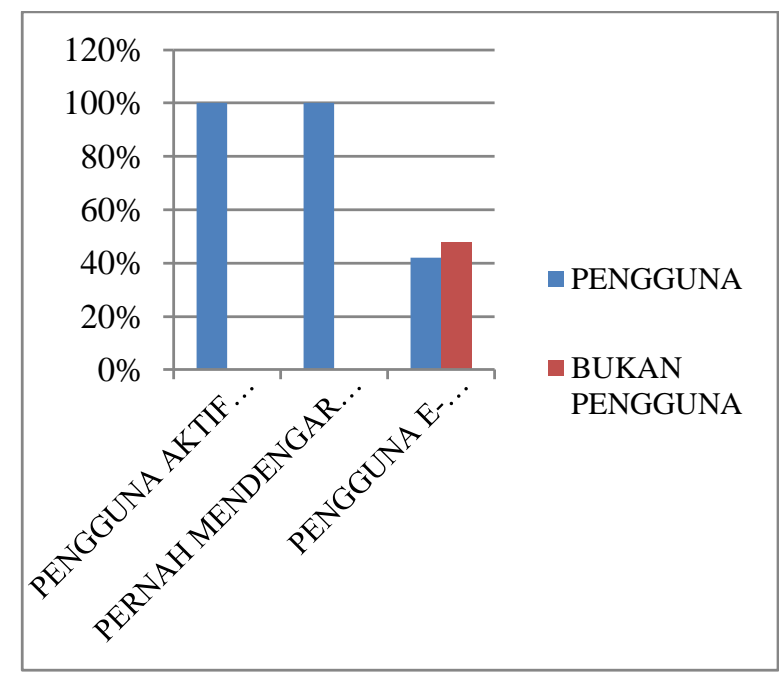

Grafik 4. Keputusan Penggunaan E-Commerce (Sumber : Data Hasil Peniliti)

Hasil di atas menunjukkan bahwa $100 \%$ perempuan pelaku UMKM di Jawa timur telah menjadi pengguna aktif internet. Istilah ecommerce juga bukan lagi menjadi sesuatu hal yang asing bagi mereka, karena $100 \%$ dari responden menyatakan bahwa mereka pernah mendengar istilah e-commerce. Keputusan para perempuan dalam penggunaan e-commerce terlihat pada Grafik 4 di atas. Dimana 48\% dari total responden telah menggunakan e-commerce dalam pengelolaan usaha mereka, sedangkan $42 \%$ nya hanya bertindak sebagai pengguna dari e-commerce.

Penelitian yang dilakukan oleh Yen Yen (2014) menunjukkan bahwa mayoritas (>50\%) UMKM di Indonesia masih berada pada level precence atau bahkan non adopter dalam hal pengadopsian e-commerce. Dimana pada level non-adopter, para pelaku UMKM belum memiliki website. Sedangkan pada level precence, para pelaku UMKM telah menggunakan website dan akun media sosial seperti facebook, twitter, Instagram dal lainlainnya. Dimana penggunaan sarana online tersebut masih terbatas pada pemberian informasi dan layanan yang bersifat 1 arah (Chandra, 2012)

Tingginya tingkat pendidikan yang dimiliki oleh para perempuan ini membuat pemikiran mereka lebih terbuka. Mereka tidak lagi menganggap teknologi sebagai sesuatu yang awam bahkan ancaman. Para pelaku UMKM di Jawa Timur telah menganggap bahwa teknologi adalah sesuatu alat serta media yang sangat dibutuhkan bagi perkembangan UMKM yang mereka miliki. Faktor usia yang matang juga merupakan salah satu pendukung para perempuan dalam mengambil keputusan untuk menggunakan e-commerce. Pada usia 40-50 tahun, perempuan telah matang dalam berfikir. Sehingga keputusan yang mereka ambil lebih rasional dan penuh pertimbangan.

Perempuan pemilik UMKM di Jawa Timur rata-rata baru memulai usaha mereka. Hal ini ditunjukkan dengan 63,4\% usaha baru berdiri dalam 1-5 tahun ini. Dari hasil tersebut kita dapat menyimpulkan bahwa para perempuan tersebut mendirikan usaha kecil baru tetapi sudah disesuaikan dengan model. Kebutuhan serta permintaan pasar saat ini. Dimana internet dan e-commerce merupakan satu gaya pemasaran masa kini.

Perempuan pemilik usaha saat ini telah memiliki tingkat pendidikan perempuan yang baik, sehingga investasi tersebut sangat berpengaruh pada kemampuan dan ketrampilan dalam mengelola usaha. Tingkat ketrampilan dan pengetahuan (pendidikan) menyangkut beberapa aspek seperti dorongan individu, hasil dan dampak, kemampuan analisa, berfikir kreatif dan strategis, ketegasan dalam pengambilan keputusan, penilaian komersial, manajemen tim dan kepemimpinan, kemampuan beradaptasi, kemampuan merencanakan serta mengendalikan suatu proyek (Ardiana dkk, 2010). Hal tersebut menyebabkan para perempuan pelaku usaha mampu menyadari bahwa penggunaan teknologi seperti ecommerce mampu menjadi suatu sarana bagi kemajuan UMKM saat ini. 


\section{PENUTUP}

Penelitian ini menunjukkan bahwa perempuan pemilik UMKM di Jawa Timur telah memiliki tingkat Pendidikan yang tinggi, dimana semua responden telah mengenyam pendidikan minimal di tingkat SMA. Dari segi usia, para pemilik UMKM mayoritas berada pada range 40-50 tahun. Dimana pada usia tersebut para perempuan sudah memiliki level pemikiran yang matang. Sedangkan berdasarkan pengalaman kerjanya mayoritas perempuan mengelola usahanya dalam range 1-5 tahun. Tingginya tingkat pendidikan menyebabkan pemikiran perempuan sudah mulai terbuka. Terbukti bahwa $100 \%$ diantara mereka merupakan pengguna aktif dari internet dan sudah tidak asing lagi dengan istilah $e$ commerce. Bahkan $48 \%$ dari perempuan telah menggunakan e-commerce untuk menunjang aktivitas bisnis UMKM yang mereka miliki.

\section{DAFTAR RUJUKAN}

Alma, B. (2013). Kewirausahaan. Bandung: Alfabeta

Ardiana, I. D. K. R. (2010). Kompetensi SDM UKM dan Pengaruhnya Terhadap Kinerja UKM di Surabaya. Jurnal Manajemen dan Kewirausahaan. Vol. 12. No. 1.

Baron, R. A. (2003). Human Resource Management and Entrepreneurship: Some Reciprocal Benefits of Closer Links. Human ResourceManagement Review, 13(2), 253-256.

Bastaman, A. dan Juffiasari, R. (2015). FaktorFaktor yang Mempengaruhi Pengambilan Keputusan Bagi Wanita untuk Berwirausaha (Studi Kasus Anggota Ikatan Wanita Pengusaha Indonesia DKI Jakarta). Prosiding Seminar Nasional 4th UNS SME's Summit \& Awards 2015

Busenitz, L., \& Barney, J. (1997). Difference Between Entrepreneurs and Managers in Large Organization: Biases and Heuristics in Strategic Decision Making. Journal of Business Venturing (12), 9-30.
Eisenhardt, K. M., \& Zbaracki, M. (1992). Strategic Decision Making. Strategic Management Journal, 13: 17-37.

Chandra, G. \&. (2012). Analysis of Level and Barriers of E-commerce Adoption by Indonesian Small, Medium, and Micro Enterprises (SMMEs). Internetworking Indonesian Journal, Vol.4/No.1 B (2012).

Chiliya, N. (2012). Impact of level of Education and Experience on Profitability of Small Grocery Shops inSouth Africa. Journal of Management Economic, p. 462-470.

Febriani. (2012). Peran Wanita dalam Pengembangan Usaha Kecil dan Menengah di Kota Padang. Jurnal Manajemen dan Kewirausahaan, Volume 3, Nomor 3

Indiworo, H. E. (2016). Peran Perempuan dalam Meningkatan Kinerja UMKM. Jurnal Equilibria Pendidikan, Volume 1, Nomer 1

Kartavianus, O. (2012). Faktor-Faktor Penentu Keputusan Pembelian Melalui ECommerce. Jakarta: Binus University.

Kementerian Koperasi dan UKM. (2017). Perkembangan Data Usaha Mikro, Kecil, Menengah (UMKM) dan Usaha Besar (UB) Tahun 2016-2017. http://www.depkop.go.id 07.08.2019.

Kementerian Komunikasi dan Informatika Republik Indonesia. (2019). Pengguna Internet Indonesia Nomer Enam Dunia. https://kominfo.go.id

Kim, S. M. (2014). The Impact of Gender and Social Networks on Microenterprise Business Performance. New Jersey: School of Social Science and Human Services.

Kotler, P. dan Keller K. L. 2007. Manajemen Pemasaran. Edisi Ke-12. Jakarta: Erlangga.

Kurniawati, E. dan Saputra, M. C. D. (2018). Behavioral Factor Influencing Indonesian Micro, Small and Medium (MSME's) Owners Decision-Making in Adopting E-Commerce. Journal of 
Entrepreneurship, Business and Economics, [S.l.], v. 7, n. 1, p. 92-105, June 2019. ISSN 2345-4695.

LPII dan BI. (2015). Profil Bisnis Usaha Mikro, Kecil dan Menengah (UMKM). www.gi.go.id 17.07.2019.

Nainggolan, Romauli. (2016). Gender, Tingkat Pendidikan dan Lama Usaha Sebagai Determinan Penghasilan UMKM Kota Surabaya. Kinerja, Volume 20, No.1, Th. 2016: Hal. 1-12

Priminingtyas, D. N. (2010). Akses Usaha Kecil Menengah (UKM) Dalam Mendapatkan Kredit Usaha Dari Lembaga Perbankan Di Kota Malang. Prosiding Seminar Internasional "The Future of Small Businesses from Accounting, Management and Economics Perspectives". Fakultas Ekonomi Universitas Jenderal Soedirman Purwokerto.

Pankaj, S. (2015). E-Commerce. New Delhi: A.P. H. Publishing Corporation.

Perguna, L. A., Imamul Huda Al Siddiq, \& Irawan. (2019). Desa Membangun UMKM: Pendampingan UMKM berbasis Village-Driven Development dalam Penguatan Ekonomi Warga Di Desa Gogodeso Kecamatan Kanigoro Kabupaten Blitar. Engagement : Jurnal Pengabdian Kepada Masyarakat, 3(2), 217-229.

Qin, Z. (2009). Introduction to E-commerce. Beijing: Tsinghua University Press.

Robbins, S. P., dan Coulter M. (2002). Manajemen Jilid 1. Edisi 13. Jakarta: Erlangga.

Saydam, G. (2005). Teknologi Telekomunikasi. (Edisi Pertama). Bandung : CV Alfabeta.

Sidarta, I. dan Sidh, R. (2014). Pengukuran Persepsi Manfaat dan Persepsi Kemudahan terhadap Sikap Serta Dampaknya Atas Penggunaan Ulang Online Shopping Pada E-commerce. Jurnal Computech \& Bisnis, Vol. 8, No. 2, pp. 92-100
Simpson, M. dan Docherty, A. J. (2004). Ecommerce Adoption Support and Advice for UK SMEs. Journal of Small Business and Enterprise Development, 11(3), 315-328. Retrieved from Emerald Grup Publishing Limited.

Sutanto, T. (2000). The Influence of Business Content and Navigation Efficiency On The Web Visitor's Satisfacion In The Context Pf Websites Supporting B2C Electroni Commerce In Indonesia. Thesis Binus University.

Tambunan, T. (2009). UMKM di Indonesia. Jakarta: PT. Ghalia Indonesia.

Tambunan, T. (2012). Wanita Pengusaha di UMKM di Indonesia: Motivasi dan Kendala. Center for Industry, SME and Business Competition Studies, Trisakti University. Published by LPFE Trisakti University 2012

Tedjasuksmana, B. (2015). Potret UMKM Indonesia Menghadapi Masyarakat Ekonomi ASEAN 2015. The 7th NCFB and Doctoral Colloquium 2014. ISSN NO : 1978 - 6522

Tundui, C., dan Tundui, H. (2011). Survival, Growth Strategies and Performance of Women Owned Micro and Small Business in Tanzania. International Journal of Business \& Management, 7(8).

Undang-Undang Republik Indonesia Nomor 20 Tahun 2008. (2008). Usaha Mikro, Kecil, dan Menengah. http://www.jdih.kemenkeu.go.id/fullte xt/2008/20TAHUN2008UU.htm diakses pada tanggal 18 Sepetember 2018

Wibisono, D. (2011). Manajemen Kinerja Perusahaan. Jakarta: Erlangga.

Wibowo. 2011. Manajemen Kinerja. Jakarta: PT. Raja Grafindo Persada

Wicaksono, G. dan Nuvriasari, A. (2012). Meningkatkan Kinerja UMKM Industri Kreatif Melalui Pengembangan Kewirausahaan dan Orientasi Pasar: Kajian Pada Peran 
Serta Wirausaha Wanita di Kecamatan Moyudan, Kabupaten Sleman,

Propinsi DIY. Jurnal Sosio

Humaniora. Vol. 3 No. 4. ISSN : 2087-1899

Yen Yen Maryeni, e. a. (2014). E-commerce Adoption in Indonesia SME. Aust. J. Basic \& Appl. Sci., 45-49 